\title{
Application of the Principles of Lean Thinking in the Post Construction Department
}

\author{
Daniel Cupertino, Tatiana G. do Amaral, Sammea A. Vilarinho and Leonardo Alencar \\ School of Civil Engineering, Federal University of Goiás, Goiás 74001-970, Brazil
}

\begin{abstract}
The increase on the competitiveness, the search on the customer satisfaction, the search by reducing waste in the civil construction were facts which helped entrepreneurs and companies to seek new ways of working, being lean construction one of the ways to get that. Studies report that the application of the lean tools in construction was carried out in an isolated way. This type of application was pointed as a major factor limiting the extent of achievement in implementing lean principles. The aim of this studies is to identify opportunities to implement the principles of lean production in the service department of a construction company in Goiás, proposing routines that try to implement the continuous improvement of its processes, eliminating waste, reducing the lead time, allow it to perform the mapping processes, applying the just-in-time and among others, providing services that add value to the customer satisfaction. It was possible to establish the average time for each step, allowing to identify possible improvements in the department, from the perspective of lean principles. The research paper concludes by pointing out the activities for the Department of Post Construction work from building companies, from lean concepts.
\end{abstract}

Key words: Lean production, lean thinking, technical assistance, post construction.

\section{Introduction}

Civil construction is extending and it is changing the thinking of many entrepreneurs. From 1990, the growing competition between companies, the increasing on the costumer's requirements and the reduction of financial resources were important facts for changing the company's way of thinking, encouraging companies to seek the highest levels of performance through investments in management and production technology [1-3].

Many companies believed that one way to gain competitive advantages are summarized in the adoption of some initiatives that generate increased productivity and quality in their products. Some managers in an attempt to combat the competition tried to join the new management in an impulsively way, without planning and knowledge. Within this scenario, the use of lean practices, from the TPS (Toyota Production System), presented as an alternative

Corresponding author: Tatiana G. do Amaral, Dr., professor, research fields: management, lean construction and lean thinking. E-mail: tatiana_amaral@hotmail.com. capable of providing greater productivity and competitiveness for organizations [4]. It happens due to the fact that lean construction is based on the success of all processes and it is directly related to their management [5].

Due to the productivity gains and the reduced rates of waste on construction site, several civil construction companies found out ways to improve its process with the implementation of the lean principles into the companies [6].

Costa et al. [2] emphasize in their studies that the literature still debates a little about the strategic issues involved in implementing the concepts of lean construction.

Civil construction activities are complex and present some specific characteristics. Picchi [7] points out some opportunities with regards to the application of these concepts in some areas of civil engineering that have not been explored yet, such as the Post Construction Department at Construction Companies, or those that were implemented in an isolated way. This is the reason that provided some limitations regarding 
the extension of the results obtained and new opportunities for the integration of concepts [6].

\subsection{Literature Review}

For the structure of this work, five lean principles were used such as: flow, value stream, value, pull and perfection and they are all proposed by Womack and Jones [8], due to its broader scope and due to the fact that it is more widely used in industry [7].

Continuous improvement of production, the maximum satisfaction of customers, the use of less resources and elimination of waste on the process are some of the goals that the lean principles try to achieve within the organizations [2]. Authors like Nahmens and Ikuma [9] cited the importance of the application of lean tools to provide a safer working environment for employees, reaching occupational accident rates that were $58 \%$ lower when compared with those companies that did not use the lean tools. The concepts of the principles can be contextualized as follows:

Understanding what is the value for specific products from the point of view of the final customer, it is the first major challenge of the implementation of lean construction [10], which is a process that identifies what is value for customers by offering products with higher aggregates value, without waste and with values that customers are willing to pay. It is necessary that the decision of building companies to produce certain products is based on the needs and desires of its target customers and not only the productive capacity of the organizations [6, 7, 11-14].

Identifying the value stream consists of separating actions of the production process into three types of actions: actions that add value to the end customer, actions that do not add value but are important for maintaining the quality of products and processes and actions that do not add value and should be eliminated immediately [13]. The objective of the value stream mapping is to understand the processes flow, materials, people and equipment. It helps to reduce the variability of products, waste and transparent procedures
$[6,7,11,12]$.

Getting a continuous flow processes, it is intrinsically linked to the transparency and knowledge of the execution steps of the product. Obtaining the continuous flow involves several departments, since interruptions cannot occur; therefore changing the mindset of the organization and support of the management are important facts to achieve this goal. Benefits such as reduced lead time, which represents the time of product design, order processing and inventory, eliminating waste and adding value to the final customer are consequences of the implementation of a continuous production flow $[6,7,11-13,15]$.

The pull production allows the company to produce their products from the final customer demand (Takt Time), and in the right quantity at the right time (just-in-time), thus smaller amounts of stocks, elimination of waste or unproductive time and increased on productivity are some benefits achieved $[6,7,11-13]$.

Perfection matches in the pursuit of continuous improvement, the search for improvement, continuous learning, transparency and standardization of processes, rapid fault detection and problem's solution of waste disposal are some of the ways to raise the performance of products seeking improvements [6, 7, 11-13].

Among the opportunities for implementing lean thinking in construction, Picchi [7] cites some tools that can assist in the integration of concepts until their implementation. Table 1 is a proposal of adapted tools from Picchi [7] for better visualization of lean principles in Post Construction Department.

\subsection{Objectives}

The objective of this research is to identify the opportunities on the application of the five lean thinking principles such as: flow, value stream, value, pull and perfection at the Department of Post Construction at Building Companies [8]. 
Table 1 Relationship between the objectives, principles and proposals for the application of lean tools.

\begin{tabular}{|c|c|c|}
\hline Objectives & $\begin{array}{l}\text { Five principles of } \\
\text { lean construction }\end{array}$ & $\begin{array}{l}\text { Proposals for the application of lean tools at the Post Construction Department in Construction } \\
\text { Companies }\end{array}$ \\
\hline \multirow{6}{*}{$\begin{array}{l}\text {-Creating } \\
\text { working } \\
\text { routine }\end{array}$} & \multirow{5}{*}{ Value } & Rationalization of the stages on customer service \\
\hline & & Reduction of service time-lead time \\
\hline & & Work performed in parallel \\
\hline & & Perform quality services and on time \\
\hline & & $\begin{array}{l}\text { Identify customer requirements through evaluations of customer's satisfaction with services } \\
\text { provided at the end of the process }\end{array}$ \\
\hline & \multirow{4}{*}{ Value stream } & Mapping the value stream and routines that eliminate steps that add no value to the customer \\
\hline \multirow{3}{*}{$\begin{array}{l}\text {-Flowchart } \\
\text { Mapping }\end{array}$} & & Creating a map of the flowchart steps that cause the most problems in the process \\
\hline & & $\begin{array}{l}\text { To carry out preliminary inspections to verify the actual severity and the causes of the requests to } \\
\text { assist in the sizing of the staff and equipment needed }\end{array}$ \\
\hline & & Forming partnerships with suppliers, so the delivery of materials could be done quicker \\
\hline \multirow{4}{*}{$\begin{array}{l}\text {-Reducing } \\
\text { waste }\end{array}$} & \multirow{4}{*}{ Flow } & Creating work cell with multifunctional professionals \\
\hline & & $\begin{array}{l}\text { To turn a workforce available to do the job without the interference of other departments, like } \\
\text { other construction fields }\end{array}$ \\
\hline & & Creating the WI (work instruction) to the Post Construction Department \\
\hline & & Creating some indicators of productivity and time for assistance on solicitations \\
\hline \multirow{3}{*}{\begin{tabular}{|l|}
- To increase \\
the \\
transparence in \\
the process
\end{tabular}} & \multirow{3}{*}{ Pull } & Takt time - Rhythm demand-It is necessary a solicitation by the client \\
\hline & & $\begin{array}{l}\text { Propose a plan of periodic inspections within the guarantee period of five years after the release } \\
\text { of the building or construction, in order to verify if the maintenance is being done, avoiding } \\
\text { future solicitations or pathological manifestations }\end{array}$ \\
\hline & & Enabling the workforce to develop several tasks \\
\hline \multirow{9}{*}{$\begin{array}{l}\text {-Eliminating } \\
\text { some stages } \\
\text { that do not } \\
\text { increase value } \\
\text { to the client }\end{array}$} & \multirow{9}{*}{ Perfection } & The responsible for the management of the department will be an engineer or an architect \\
\hline & & Creating a structured Post Construction Department and self-manageable \\
\hline & & Training the workforce on the lean practice \\
\hline & & Effective communication \\
\hline & & $\begin{array}{l}\text { Propose a more didactic manual's property and make speeches about the importance of } \\
\text { building's maintenance in its lifetime }\end{array}$ \\
\hline & & $\begin{array}{l}\text { Create a database that enables to include helpful information into the productive system, in order } \\
\text { to avoid future failures }\end{array}$ \\
\hline & & Make periodical training with the building manager \\
\hline & & $\begin{array}{l}\text { Make meetings with several facilities of the company, looking forward to exchange knowledge } \\
\text { to seek continuous improvement on the processes }\end{array}$ \\
\hline & & Strategic compromise with the top management in application of lean tools \\
\hline
\end{tabular}

\section{Methodology}

According to the proposed objectives, this research paper is exploratory, because we seek a better understanding and improvement on methods of application of lean tools in the Post Construction Departments of Building Companies. The methodology used to make this project fits in action-research, considering that some researchers are involved in some of the companies that were part of the collected data.

On the first step, a literature review on the five principles of lean thinking such as value stream, value, flow, pull and perfection was done. Later on a connection was made between the research objectives, the five principles of lean thinking and lean tools that could be used within the Department of Post Construction of Building Companies.

On the second step, it was thought to conduct a study of several cases to acquire knowledge on how the Post Construction Department of the state's construction companies is developed in relation to lean practices. In order to get that, a semi-structured interview was developed with the responsible for the department of 
each company. Five consolidated companies in the state's market were chosen, working on civil construction industry for vertical multifamily housing developments.

Among the participating companies, the Company Letter D is the only one which does not have a Post Construction Department formed, but due to the volume of works that have been delivered and are being implemented, the top management department noted the need to implement a Post Construction Department in a near future. The management support, the participation of a member from the technical group of employees were decisive for the companies to develop the guidelines for the department, which will support its implementation.

Some specific goals may also be listed, such as: align routine actions with strategic goals and map the process flow related to the use and maintenance of buildings, which may be a difference searching for strength and profitability of the companies [16].

As a way of supporting the objectives of this research, using the literature, some of the tools were selected within each principle of lean construction presented in Table 1. Developing lean tools adapted to the Post Construction Department of a Building Company like: analysis of the flowchart mapping and lead time activities, planned inspections and technical support form.

\section{Data Collection}

Semi-structured interviews were performed in each company, seeking to understand the organization of the Post Construction Department, its activities and its principles. The questions are presented below:

- Is there a Post Construction Department which carries out the technical assistance?

- How is the procedure for technical assistance since the customer until the delivery of the service conducted by the company? Can the company describe it?

- How is the assessment or refusing requests for customer service?

- Are there flow charts or work instructions that the company has adopted to standardize the technical assistance?

- Are staffs trained to perform these services? Is a qualified professional who performs the first inspection? Is this professional registered by CREA?

- What about the average time that the company spends to meet the maintenance demands of customers (for example, first contact with the client and schedule for completion of service)? How is the evaluation of delivery of the services performed?

- How are requests registered and monitored (tabulate and store)? Is there any way of tabulating these data to feed back into the production system for the next projects?

- How many projects does the company have built over the past five years and how it runs now?

- Does the company welcome the idea to develop a Post Construction Department as a preventive measure to post construction to meet future demands of its customers in a faster and better way?

- Is there an indicator developed in the Post Construction Department in a way to produce and control the services performed and the indicators for customer's satisfaction?

\section{Data Analysis}

The identification of business will be protected, each being assigned a company identification by means of letters (A, B, C, D). All the companies contacted were receptive to answering all the questions raised on the interviews. The directors of companies A, C and D participated in semi-structured interview to answer the questions in person, however, the responsible for Company B responded to questionnaire electronically.

Regarding to the existence of a Post Construction Department, Companies A, B and C stated that there is a Post Construction Department with some variation between them due to the volume of works to be met, however, Company D sees the need to create such a 
department in the near future for its customers.

Regarding to the procedures of the companies A, B and $\mathrm{C}$, they have operating procedures, by some called "OP (operating procedures)", by others "EPIS (Execution Procedure and Service Inspection)" or even "WI (Work Instructions)", the Company D is trying to develop its procedures. The Companys $\mathrm{B}$ and $\mathrm{C}$ mentioned that the disclosure of their documents is not a practice carried out by the company and therefore they could not turn their operating procedures available.

It is a common practice in all of the studied companies that all the customer requests made in by the customers must be made in hand writing or by telephone to the Technical Assistance Department of the Company. All the requests are usually received and the department contacts the costumer in order to schedule the date of the inspection, conducted jointly with an engineer or technician responsible for the department to register the occurrence and then proceed with the execution of the service, mobilization of material, equipment and labor work required.

It was observed within the interview that in some cases the first inspection in Company $\mathrm{C}$ is not performed by the engineer responsible for the Post Construction Department, but by someone encharged which is not recommended, due to the fact that the recording and analysis of the causes are not made by a formal technical knowledge. Both companys A and B confirmed that the first inspection of the customer's request is made by the engineer responsible for the department.

At the end of each Technical Assistance Service, the department conducts a quest with the client regarding to its services. In order to manage the technical assistance services in common areas, the engineer adopts the same procedure used for the units, but the building manager is responsible for requesting and tracking the services. In every company, except Company D, the Summary of Requests for Technical Assistance is presented in a technical meeting at the end of the month in order to discuss with all the stakeholders, trying to take corrective and preventive actions whenever it is necessary.

In the assessment related to the time required to meet the request, it was found that there are different times of attendance. The average time that companies use to make the first contact with the customer to provide feedback to a request for technical assistance and to schedule a technical visit takes $24 \mathrm{~h}$ to $48 \mathrm{~h}$. Regarding to an implementation of a service, there is no accurate time required for completing the service, considering that there are variations due to the type of problem to be solved, ranging from one day to one week.

\subsection{Flowchart Mapping and Lead Time of Activities}

In Table 1, it can be observed that the flow mapping and elaboration of the mapping activities of the Post Construction Department can be framed in search for the attendance on the lean principle relating to the value stream and the attempt for reducing the lead time activities can be seen as a service to the lean principle related to the value. Fig. 1 shows how the activities of the Post Construction Department were identified and their respective estimated lead time. Fig. 2 represents the proposed activities for the Post Construction Department and the respective reduced lead time.

Reducing lead time at Post Construction Department was only possible with the implementation of a technical assistance (architect or engineer) which is in direct contact with the client, setting up an inspection directly technical/customer, and the preceding judgment by the technician, due to the fact that many times, this previous judgment could be done at the inspection. Beforehand, due to the fact that it was someone encharged to do the inspection, he or she did not have that authority and sometimes, he or she did not even have the appropriate knowledge.

After the solicitation judgment, the technical staff used to do the quantification of the technical staff, materials and schedule of the activities. The technician used to follow the inspection with the client and he or 


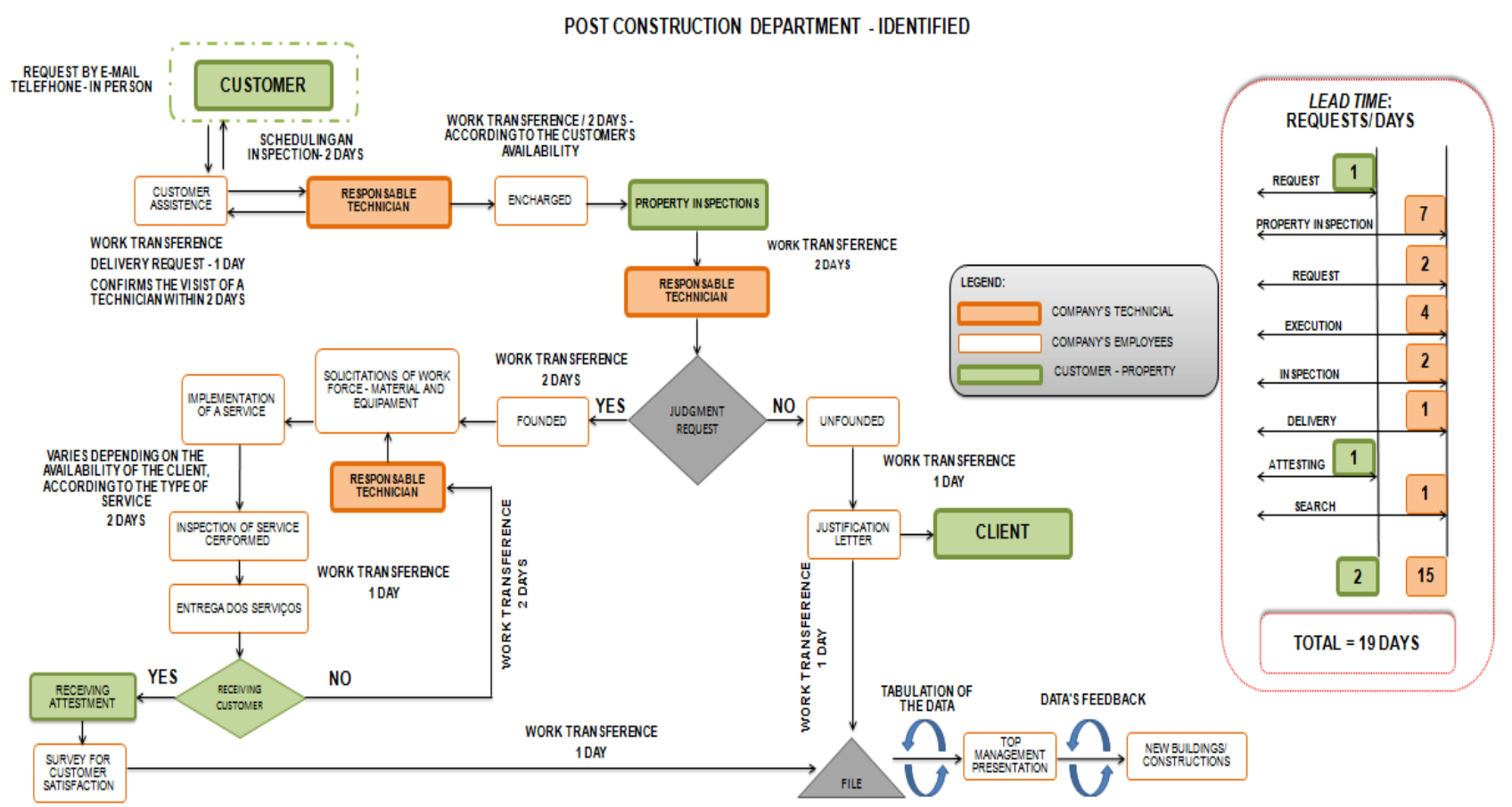

Fig. 1 Identified activities in the Post Construction Department and estimated lead time.

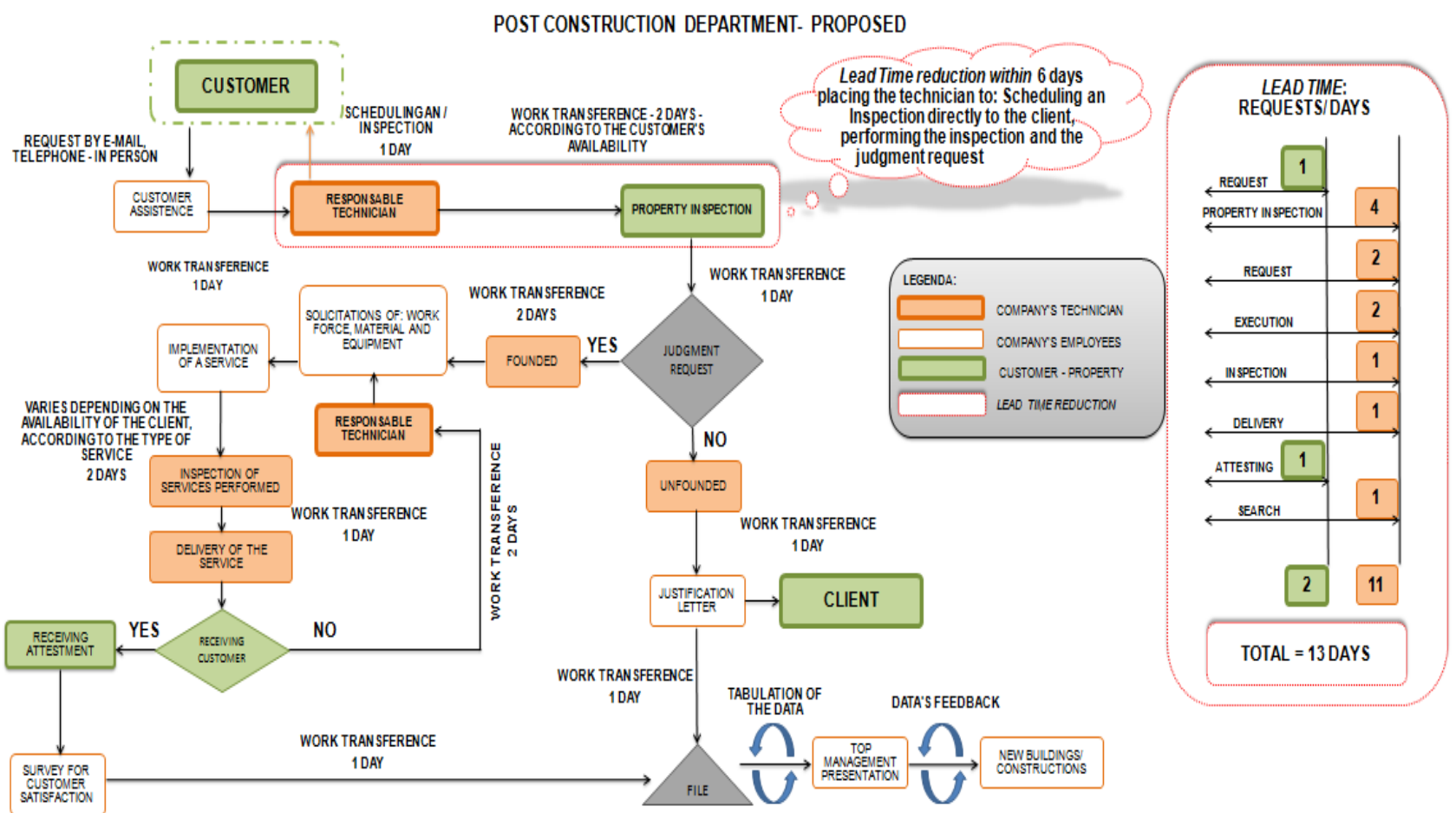

Fig. 2 Proposed activities for the Post construction Department and the reduced lead time.

she used to release the service to the client. This monitoring and final inspection before releasing the service to the customer, it was possible to detect problems within the implementation and future measures by the receiving client. It was found that the presence of a technician at all the stages helps to reduce the variability and a reduction of errors and delays in delivering services to the customer. 


\subsection{Planned Periodical Inspections}

In order to propose a tool based on the lean principle referring to the pull concept, it is presented a way of planned intervention, based on preventive maintenance of buildings, in order to increase the useful life of buildings thus restoring a satisfactory level of performance for buildings. The implementation of these maintenance services may be offered by their own construction companies to the customers, via contract, so that the construction company can perform the services required guaranteeing the final product. In Table 2, an action plan is proposed with the frequency of preventive maintenance and inspections for building construction system that must occur from time to time in advance, from the release of the project.

\subsection{Technical Assistance Request Form}

The technical assistance request form aims at helping small and medium sized construction companies develop a Technical Service Department and to therefore meet the lean principle referring to perfection, seeking to standardize records, increasing transparency and the control of services. The use of this form will enable the company to register all customer's requests, to follow all stages of execution, register the costs regarding each request, register the team required for each type of activity, the engineer responsible for implementing each step, as well as the result of the customer satisfaction survey. In order to prepare the technical assistance request form, Microsoft Office Excel 2007 was used, along with Poka-Yoke concepts [17]. We have included a filled-in form (Fig. 3) in order to exemplify the use of the Technical Assistance Request form for plumbing installations.

Fig. 4 presents some results that can be obtained by the tabulation of some data's request in 2011.

\section{Conclusions and Final Considerations}

Participating companies proved to be aware and understand the importance of a Post Construction Department and its activities with the customers.

Among the difficulties found it is worth highlighting the measurement of average service time, considering that the lead time varies considerably depending on the type of activity that must be developed to meet the client's request.

The demand is another important key point for the analysis, because some companies do not have enough demand for services related to the request for technical assistance to maintain specific staff for the Post Construction Department. Faced with the discontinuity

Table 2 Periodicity of preventive maintenance and inspections.

\begin{tabular}{|c|c|c|c|c|c|c|c|c|c|c|c|c|}
\hline \multirow[b]{2}{*}{ Item } & \multirow[b]{2}{*}{$\begin{array}{l}\text { Constructive } \\
\text { system }\end{array}$} & \multicolumn{10}{|c|}{ Time } & \multirow[b]{2}{*}{$\begin{array}{l}\text { Frequency of } \\
\text { servicing }\end{array}$} \\
\hline & & 6 months & 1 year & $\begin{array}{l}1 \text { year and } \\
\text { a half }\end{array}$ & $\begin{array}{l}2 \\
\text { years }\end{array}$ & $\begin{array}{l}2 \text { years } \\
\text { and a } \\
\text { half }\end{array}$ & 3 years & $\begin{array}{l}3 \text { years } \\
\text { and a } \\
\text { half }\end{array}$ & 4 years & $\begin{array}{l}4 \text { years } \\
\text { and a } \\
\text { half }\end{array}$ & 5 years & \\
\hline 1 & Concrete Structure & & $*$ & & $*$ & & $*$ & & $*$ & & $*$ & Every year \\
\hline 2 & Metallic structure & & & & $*$ & & & & $*$ & & & Every 2 years \\
\hline 3 & Waterproofing & & $*$ & & $*$ & & $*$ & & $*$ & & $*$ & Every year \\
\hline 4 & Hydraulic Installation & & & & & & $*$ & & & & & Every 3 years \\
\hline 5 & $\begin{array}{l}\text { Sanitary wares and } \\
\text { sanitary metals }\end{array}$ & & & & $*$ & & & & $*$ & & & Every 2 years \\
\hline 6 & Electrical Installation & & $*$ & & $*$ & & $*$ & & $*$ & & $*$ & Every year \\
\hline 7 & Wall coverings & & & & $*$ & & $*$ & & $*$ & & $*$ & Every 2 years \\
\hline 8 & $\begin{array}{l}\text { Inside and outside } \\
\text { Painting }\end{array}$ & & $*$ & & $*$ & & $*$ & & $*$ & & $*$ & Every year \\
\hline 9 & Covering system & & & & $*$ & & & & $*$ & & & Every 2 years \\
\hline 10 & Glasses & & & & $*$ & & & & $*$ & & & Every 2 years \\
\hline 11 & & $*$ & $*$ & $*$ & $*$ & $*$ & $*$ & $*$ & $*$ & $*$ & $*$ & $\begin{array}{l}\text { Every } 6 \\
\text { months }\end{array}$ \\
\hline 12 & & & & & $*$ & & & & $*$ & & & Every 2 years \\
\hline
\end{tabular}




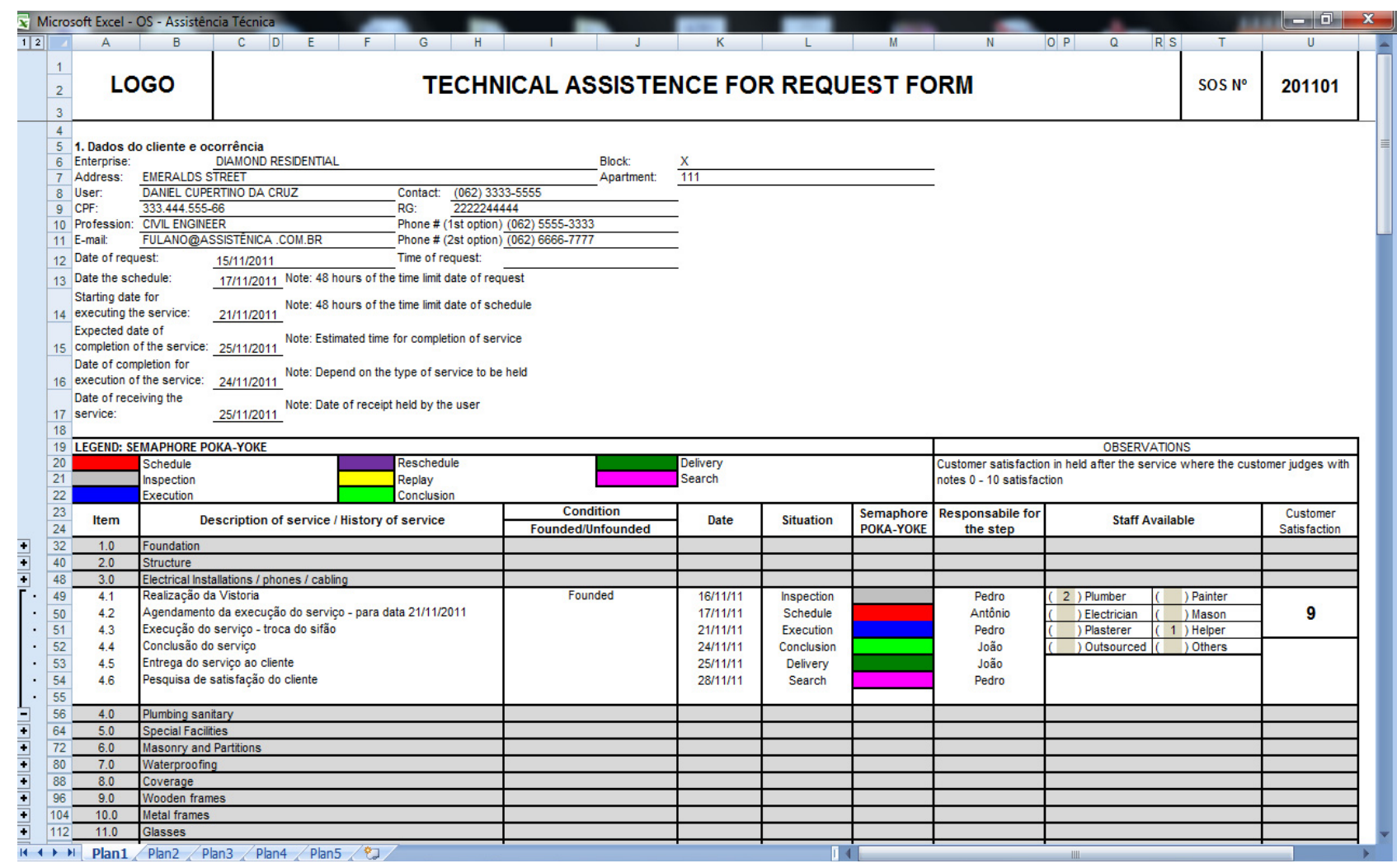

Fig. 3 Filled form of technical assistance for hidro-sanitary installation.

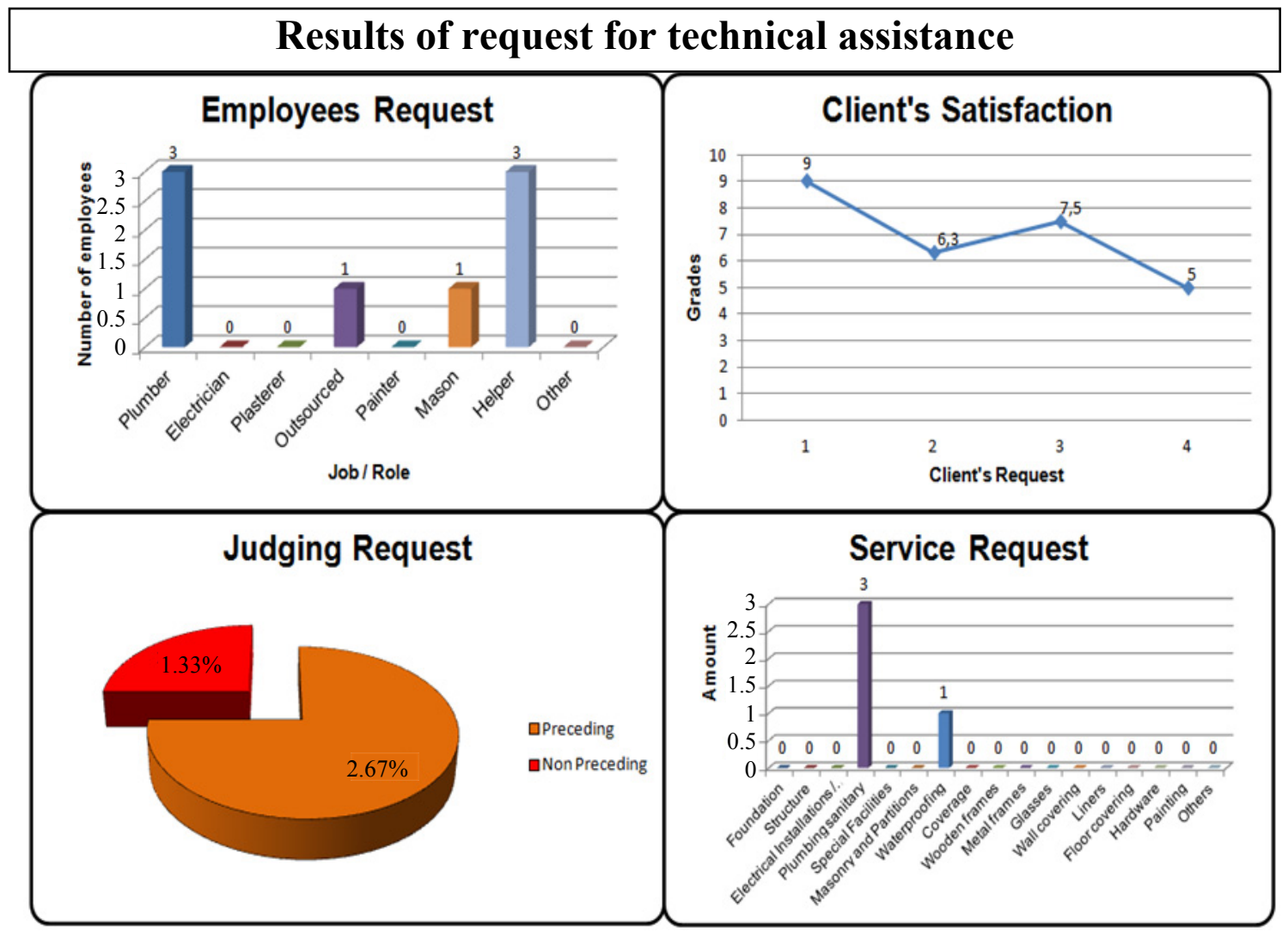

Fig. 4 Presentation of some tabulated results from technical solicitations. 
of services employees are relocated to other service fronts and when necessary, they stop what they are doing to meet the request for technical assistance.

The discontinuity of production flows when removing an employee from construction works to carry out another service should be taken into consideration when planning activities since according to the lean principles, the continuous flow of activities must be met.

One way of compensating for this discontinuity would be a monthly analysis of requests in order to identify the services with higher demands and promoting appropriate training for employees so that they become multi-functional, as such specializing the workforce.

It was observed that there are many points that can be improved in the Post Construction Department with the lean tools, and the proposed operating procedures, technical request forms, flowchart mapping of activities, planning in the inspections in advance were some tools used on this research paper to demonstrate that it is possible to meet the lean principles: value, value stream, flow, pull, perfection, in the search for continuous improvement, transparency and processes' control.

\section{References}

[1] J.P.B. Neto, T.C.L. Alves, L.V.M. Abreu, Strategic aspects of lean construction, in: The 5th Brazilian Symposium on Management and Economics Building, Campinas, 2007. (in Portuguese)

[2] G.S. Costa, M.J. Azevedo, J.P.B. Neto, Approach to competitive criteria of production companies in production at companies that have implemented lean construction in Fortaleza, in: The 6th National Congress of Management Excellence. Niterói, Rio de Janeiro, 2010. (in Portuguese)

[3] I.A. Lorenzon, R.A. Martins, Talk about performance measurement in lean construction, in: The Proceedings of 13th Symposium of Production Engineering, Bauru, SP, 2006. (in Portuguese)

[4] R.K. Macedo, Propose a method to measure the degree of implementation of lean practices into a company that does not have a structured lean system: A case study, Master Thesis, Production and Systems, University of Vale do
Rio dos Sinos, São Leopoudo, 2010. (in Portuguese)

[5] L. Koskela, S. Bertelsen, C. Bosch, Theory championship, in: The Proceedings of International Group for Lean Construction (IGLC 12), Elsignore, Denmark, 2004.

[6] F.A. Picchi, A.D. Granja, Application of lean thinking to the flow of work, in: Proceedings of the First Latin American Conference on Sustainable Building Technology, São Paulo, 2004. (in Portuguese)

[7] F.A. Picchi, Opportunities for the application of lean thinking in construction, Magazine ANTAC Built Environment 1 (2003) 1-23. (in Portuguese)

[8] J.P. Womack, D.T. Jones, Lean Thinking in Business-Eliminate Waste and Create Wealth, Rio de Janeiro, Campus, 1998. (in Portuguese)

[9] I. Nahmens, L.H. Ikuma, An empirical examination of the relationship between lean construction and safety in the industrialized housing industry, Lean Construction Journal 1 (2009) 1-12.

[10] F. Battaglia, Dare to think beyond lean factory, Lean Institute Brazil, São Paulo, SP, 2007. (in Portuguese)

[11] J.A.R. Almeida, Elaboration of a method for improving information flows using principles of lean thinking and process reengineering, Master Thesis, Graduate Program in Production Engineering and Area of Concentration Processes and Operation Management, School of Engineering of São Carlos, University of São Paulo, 2009. (in Portuguese)

[12] B.J. Hicks, Lean information management: Understanding and eliminating waste, International Journal of Information Management 27 (2007) 233-249.

[13] Lean Institute Brasil, Concepts and Applications, http:// www.lean.org.br (accessed Oct. 24, 2011). (in Portuguese)

[14] L.S. Salermo, Application of tools of lean thinking and autonomous maintenance to maintenance of building water systems, case study services: Teaching hospital of UNICAMP, Master Thesis, State University of Campinas, Faculty of Civil Engineering, Architecture and Urbanism. Campinas, São Paulo, 2005. (in Portuguese)

[15] L. Santana, Research actions regarding lean construction builders in Goiás, Master Thesis, Federal University of Goiás, School of Civil Engineering, Goiânia, 2010. (in Portuguese)

[16] G.S. Costa, E.S. Rola, M.J. Azevedo, A discussion of competitive criteria production companies implanted lean construction, in: 33rd National Association of Graduate and Research Administration, Anpad, São Paulo, 2009. (in Portuguese)

[17] M. Zárate, S. García, E. Castañarea, M. Davis, Lean Principles Inmobiliaria en la Postventa. ELAGEC IV-Latin American Encounter of Gestión de la Construcción y Economía.Santiago, Chile, 2011. 